\title{
Az engedetlenség kötelessége - a modern politika egyik forrásánál
}

\section{MOLNÁR ATTILA KÁROLY ${ }^{1}$}

A tanulmány nem az alkotmányos ellenállás (ius resistendi) magyar, angol vagy lengyel ösi fogalmával foglalkozik, hanem az engedetlenség - ami nem politikai vagy erkölcsi lehetőség, hanem kötelesség - képzetének kialakulásával. A háború utáni politikai és erkölcsi gondolkodás hangsúlyozta, a természet törvény fogalmával együtt, az engedetlenség, parancsmegtagadás erkölcsi, sőt jogi kötelességét az igazságtalan törvény vagy parancs esetében. Noha a politikai gondolkodásban hagyományosan a fó probléma az volt, hogyan kerüljék el a lázadást, amely a politikai közösséget örökké fenyegeti, a lelkiismeret fogalma köré épülö keresztény erkölcsi gondolkodás története ezzel ellentétes fogalmat eredményezett, az engedetlenség kötelességének a fogalmát. A skolasztikában a tévedékeny lelkiismeret problémája vezetett a Szent Tamás és Szent Bonaventura közti vitához, amelyben az első amellett érvelt, hogy a lelkiismeretet minden esetben követni kell, akár az autoritással szemben is, míg a második azt irta, hogy a lelkiismeret és az autoritás ütközése esetén a lelkiismeretet félre kell tenni, mivel tévedhet. Az engedetlenség erkölcsi kötelességének képzete nyilvánvalóan Szent Tamásnak az ebben a vitában kifejtett érveléséböl ered.

Kulcsszavak: lelkiismeret, engedetlenség, Szent Tamás, Szent Bonaventura

\section{The Obligation to Be Disobedient - A Root of Modern Political Imagination}

This paper does not deal with the notion of constitutional resistance (ius resistendi), an ancient notion in Hungary, England or Poland, instead it focuses on the emergence of the notion of disobedience as not a political or moral opportunity, but a moral duty. The post-war political and moral imagination has emphasised - alongside with the notion of natural law the moral (even legal) duty of disobedience in case of unjust law or order. Although in the political thinking the mainstream problem was how to cope with the rebel as an eternal danger for political community, the history of Christian moral thinking, arranged around the idea of conscience, produced the opposing notion of the duty of disobedience. In the Scholastic thinking,

1 Intézetvezető, Nemzeti Közszolgálati Egyetem, Eötvös József Kutatóközpont, Molnár Tamás Kutatóintézet; e-mail: molnar.attila.karoly@uni-nke.hu 
the problem of fallible conscience led to a debate between St. Thomas Aquinas and St. Bonaventura in which the first one argued that conscience should follow in any case, even against authority, while the second wrote that in case of conflict between one's conscience and an authority, conscience should be put aside because of its potential fallibility. The modern notion of the moral duty of disobedience is rooted in Aquinas's argument in the debate.

Keywords: conscience, disobedience, St. Thomas, St. Bonaventura

Számunkra, magyarok számára, a ius resistendi képzete az Aranybulla óta az ősi alkotmányunk fontos eleme volt, akárcsak az angolok vagy a lengyelek esetében. A megoldandó probléma az volt, hogy a zsarnokká váló uralkodóval szemben tehet-e valamit a jó keresztény, aki számára világos, hogy Lucifer, majd Ádám lázadását megismételni a legfőbb bűn (Róm 13,1-5). Azonban e dolgozatban nem a zsarnokkal szembeni alkotmányos ellenállásról kívánok írni, hanem a személyes engedetlenség kötelességéről, amely először az egyháziaknál jelent meg, de minden hierarchikus intézményben felmerülhet. Nem az a kérdés pusztán, hogy joga van-e valakinek ellenállni, hanem az, hogy kötelessége-e ellenállni. Ellenállás és engedetlenség mindig volt az írott történelemben, az európai kora modern és modern kultúra sajátossága viszont az, hogy az engedetlenséget erkölcsi kötelességgé tette, előbb a kárhozat veszélyére hivatkozva, majd a legújabb korban minden különösebb indoklási kísérletet mellőzve.

Az engedetlenség erkölcsi kötelességének gondolata, amelyet Martin Luther és a reformátorok népszerüsítettek, a skolasztika lelkiismerettel kapcsolatos vitáiból ered. A lelkiismeret-fogalom előtörténete szétfeszítené ezen írás kereteit. Elég itt most annyit megjegyeznem, hogy a patrisztikában lett a lelkiismeret cselekvést motiváló: a kellés forrása a menekülés a lelki gyötrelmektől és a vágyakozás a már földi életben megtapasztalható isteni áldásra, ami a nyugodt, zavartalan és jó lelki állapot. A büntetésre tehát nem kell várni a halál utánig, már e világon eljő.

A görög (rossz) lelkiismeret-fogalommal szemben az ókeresztény szerzőknél a jó lelkiismeret jelentősége megnőtt, mivel a jó lelkiismeret és az igazság (Isten) összefüggenek: a „lelkiismeretem gyönyörködik, lelkem örül, hogy az igazság fényében sütkérezhet”. ${ }^{2}$ Ennek eléréséhez kell az önvizsgálat és a penitencia. A lelkiismeret egyre növekvő szerepet kapott az üdvbizonyosságban, hiszen a bünösnek nincs lelki békéje az őt mardosó rossz lelkiismeret miatt. A lelkiismeret rossz állapotát az üdvösséggel ritkán kapcsolták össze olyan világosan, mint Sevillai Szent Izidor a Sententiaeben:

„Míg az emberi állapot összezavarja a tudatot sokféle romlottsággal, az már azelőtt elszenvedi a lelkiismeret büntetését, még a pokol büntetése előtt, a lélek összezavart vágyakozásaival. Az ember minden elől elszökhet, kivéve a szívét. Ugyanis

2 Lactantius: Isteni tanitások. Ford. Dér Katalin. Budapest, Kairosz, 2012. 353. 
senki sem menekülhet maga elől. Akárhová menne is, a bűntudata nem hagyja el. Még ha minden rossztevő el is szökhetne az emberi ítélet elől, nem lennének képesek elmenekülni a lelkiismeretük ítélete elől. Ugyanis az, aki képes mások elől elrejteni, amit tett, nem képes maga elől elrejteni, és felismeri mit tett rosszul. Tehát kétszeres ítélet sújtja, ugyanis itt és most megbünteti a lelkiismerete, és emellett a túlvilágon is megbüntetik." ${ }^{3}$

A lelkiismeret Isten ítélete az egyénről, s nem csupán egyes tetteiről, s ebből már a földi életben tudhatja, mi vár rá az utolsó ítéletkor. Ha a lelki jólét és elégedettség szubjektív tapasztalatát csak a jó lelkiismeret adhatja, akkor a jó lelkiismeret tapasztalata remény az üdvösségre. Mivel Istentől ered a tiszta lelkiismeret és az alázatos tudat, ezek az új ember, a kegyelem jelei. ${ }^{4}$

A jó lelkiismeret annyit jelentett, hogy valaki teljesítette az Úr elvárásait, és ezért nyugodtan várja a jutalmát, nem aggódik. ${ }^{5} \mathrm{~A}$ jó lelkiismeret jel volta mellett mindenek feletti öröm, élvezet: „a lelkiismeret nyugalma s a büntelenség biztonsága maga is létrehozza a boldog életet". ${ }^{6}$ A lelkiismeret nyugalma a legfontosabb, ${ }^{7}$ mert az öröm és a béke a tiszta lelkiismeret, ami az igaz keresztény, az igazság ismeretének és megtételének jele, és együtt jár a bizonyossággal: „a bizonyosság derűje ömlött el szívemben, és a kételkedés minden homálya szertefoszlott." ${ }^{8}$ A kegyelem tehát tiszta lelkiismerettel és bátorsággal jár. ${ }^{9}$ Szeretet, hit és jó lelkiismeret együtt járnak, hiszen „a hit titka a tiszta lelkiismeret", ${ }^{10}$ bár nincs kifejtve, hogyan. Ahogyan az Isten parancsa iránti engedelmesség feltétlen parancs, úgy lett idővel a lelkiismeret „parancsa” iránti engedelmesség is az. A patrisztikában szilárdult meg és terjedt el a lelkiismeret hangja és az Isten parancsa közti szoros kapcsolat feltételezése. Emiatt lehetett később a jó lelkiismeret tapasztalata és a belőle eredő magabiztosság mindenekfelett álló érv a politikai és erkölcsi vitákban. A jó lelkiismeret azért áll felette az emberek ítéletének, mert a jó lelkiismeret közvetlen forrása Isten, „aki feloldozza a lelkiismeretet”. ${ }^{11}$

A lelkiismeret már elvesztette az eredeti, „másokkal közös tudás” jelentését, de az igazság ismerőjeként szembe is fordíthatná az embert a többiekkel és a bűnös

3 Isidore: Sententiae. II. könyv, caput XXVI, De conscientia. 1-4. Idézi Anders Schinkel: Conscience and Conscientious Objections. Amszterdam, Vrije Universiteit, 2007. 169.

4 Athanasius: Letter I. In Athanasius: Select Works and Letters. Szerk. Philip Schaff - Henry Wace. Grand Rapids, Eerdmans, 1987. 897.

5 St. Ambrose: The Treatise concerning Widows. In St. Ambrose: Selected Works and Letters. Szerk. Philip Schaff - Henry Wace. Grand Rapids, Eerdmans, 1989. 12. fejezet, 74. pont, 939.

6 Szent Ambrus: A kötelességröl. A bünbánatról. Ford. Hrotkó Géza - Meggyes Ede - Tóth Vencel OFM, Budapest, Jel, 2004. 163.

7 St. Augustine: Letter LXXIII. In St Augustine: The Confessions and Letters of St. Augustin. Buffalo, The Christian Literature, 1886. 333.

8 Aurelius Augustinus: Vallomások. Budapest, Gondolat, 1982. 242.

9 Athanasius, Letter LII. In Athanasius i. m. (4. lj.) 975.

10 1Tim 3,9; St. Jerome: Letter XIV to Heliodorus. In Philip Schaff (szerk.): The Principal Works of St. Jerome. New York, Christian Literature, 1892. 83.

11 St. Ambrose: Epistle LVII. In St. Ambrose i. m. (5. lj.) 10. szakasz, 1036. 
világgal, hiszen a többiek megbecsülésénél, a dicsőségnél és a büszkeségnél fontosabb a jó lelkiismeret. ${ }^{12}$ A többi ember előtti szégyen nem minősíti egy cselekedet jó vagy rossz voltát.

$\mathrm{Az}$, apostol nem vette figyelembe az emberek dicséretét semmilyen nagyszerü tettéért, máshol azt mondja: »1Kor 4,3 A magam részéről nem törődöm azzal, hogy ti vagy más emberi bíróság mint ítéltek felőlem, hiszen önmagam fölött sem ítélkezem.« Máshol pedig ezt: »Gal 1,10 Ha még emberek tetszését keresném, nem volnék Krisztus szolgája.« [...] [A] legnagyobb óvatosság esetén sem tudja az ember elkerülni a legrosszindulatúbb gyanakvást, még ha a jó hírünk kedvéért mindent megteszünk, amit helyesen tehetünk. [...] [L]egyen nyugodt a lelkiismeretünk és örömünk abban, hogy a jutalmunk a Mennyben van, még ha az emberek rosszakat is mondanak rólunk, de istenesen és igazan élünk."13

Az emberi ítélet többnyire téves, azt nyugodt és tiszta lelkiismeret esetén megvetni lelki erőt jelent, ${ }^{14}$ ugyanakkor - ha nem is keresendő a többi ember helyeslése kerülendő a megbotránkoztatása.

Szemben a pogány görög lelkiismeret-fogalommal a keresztény lelkiismeret ítéletének nem alapja a többi ember helyeslése. ${ }^{15} \mathrm{~A}$ jó lelkiismeret önmagában jó, az emberek dicsérete azonban nem feltétlenül tesz jóvá. Isten a „lelkiismeret kutatója. És ami a tiszta lelkiismeretből ered, dicséretesebb, mint ami az emberek dicséretének vágyából" ${ }^{16}$ Isten keresése fontosabb, mint az emberek véleményéé, és mivel Isten csalhatatlan, ${ }^{17}$ ezért a lelkiismeret helyeslése elegendő, nem kell a többi ember megbecsülése. „Nem keresem mások tiszteletét, a lelkiismeretem helyeslése elegendő számomra."18 Ugyanakkor a jó lelkiismeret nem fél a nyilvánosságtól. Bár elvesztette a közös tudásra vonatkozó pogány jelentést, nem feltétlenül fordítja szembe a többi ember véleményével az embert. „A jó lelkiismeret nem fél senki szemétől. [...] Imádkozz, nyisd ki a füled az egész város felháborodására." ${ }^{19}$ Azonban bármennyire is kapcsolatban áll az igazsággal a lelkiismeret, a patrisztikában rá hivatkozva nem lehet a világi törvényekkel szembefordulni, Istennek, sőt a világi törvényeknek engedelmeskedni kell a lelkiismeret kedvéért. ${ }^{20}$

A patrisztika rejtett vitája a körül zajlott, hogy mindenkinek van-e lelkiismerete. Ha nincs, akkor nem mindenki felelős a tetteiért, hiszen nincsen tudása a jóról. Ha mindenkinek van, akkor viszont hogyan térhetnek el tőle? Erre a patrisztika nem

12 Szent Ágoston: Isten városáról. Budapest, Kairosz, 2005. I. kötet, V. könyv 12. fejezet és II. kötet, XII. könyv 8. fejezet.

13 St. Augustin: Of the Good of Widowhood. In Philip Schaff (szerk.): St. Augustine on the Holy Trinity. Doctrinal Treatises. Moral Treatises, III. Buffalo, The Christian Literature, 1887. 27.

14 Szent Ágoston i. m. (12. lj.) I. kötet, I. könyv 22. fejezet.

15 Uo. II. kötet, XIV. könyv 18. fejezet.

16 St. Augustine: Sermon on the Mount. In St. Augustine: Sermon on the Mount. Harmony of the Gospels. Homilies on the Gospels. Szerk. Philip Schaff. Grand Rapids, Eerdmans, 1886. II.1.

17 Szent Ambrus i. m. (5. lj.) 59. Vö. St. Ambrose i. m. (5. lj.) 939.

18 St. Jerome: Letter XIV to Heliodorus. In St. Jerome i. m. (10. lj.) 82.

19 St. Jerome: Letter CXVII. to a Mother and Daughter Living in Gaul. In St. Jerome (i. m. 10. lj.) 353.

20 Lactantius i. m. (2. lj.) 506. 
adott kidolgozott választ, ezt a skolasztika próbálta meg a synderesis és conscientia megkülönböztetésével és rendszerező összekapcsolásával. E megkülönböztetést majd a skolasztika dolgozta ki, és ezzel magyarázta, hogy miért sokféle a lelkiismeretünk parancsa a gyakorlatban, azaz a lelkiismeret parancsát követve miért kerülhetnek szembe, mondhatnak ellent egymásnak az emberek.

A patrisztika lelkiismeret-fogalma előre is mutat (antecedens), azaz cselekvésekről dönt, és nem csak visszafelé, nem csak utólagos ítélet (subsequens vagy consequens) a múltbeli tettekről. ${ }^{21} \mathrm{~A}$ patrisztikában a lelkiismeret bíró és törvényhozó, amelynek ítéletét követni kell. A lelkiismeret parancsa követésének kötelessége lett jóval később az egyéb kötelességekkel szembeni ellenállás alapja, amit A rómaiakhoz írt levél eredetileg nem lelkiismerettel kapcsolatos, de már Szent Jeromos által hozzá kapcsolt felszólítása erősített meg. „Kövesse mindegyik a meggyőződését!”22 Aki nem követi a lelkiismerete parancsait a cselekvésben, az a legnyomorultabb állapotba jut.

Ha a lelkiismeret a bíró is (subsequens vagy consequens lelkiismeret), akkor milyen törvény alapján ítél, és honnan ismeri azt? A latin sztoikus válasz az volt, hogy a conscientia tartalmazza a természeti törvény ismeretét. A conscientia e tulajdonsága átkerült a syneidesisbe is Aranyszájú Szent János írásaiban, ${ }^{23}$ aki szerint a syneidesis a belénk ültetett természettörvény (a lex nata, lex naturalis Szent Ágostonnál is előfordul). Mivel Isten beleírta a természet törvényét minden emberbe, a bűnös is ismeri azt, ezért felelős. ${ }^{24} \mathrm{Az}$ atyák szerint a conscientia egy belső hang, amely az isteni törvényt és a belőle fakadó kötelességeket mondja meg, és büntet megsértésük esetén. Mivel ragaszkodtak ahhoz, hogy mindenkinek van lelkiismerete, belső bírája, ezért el kellett fogadni, hogy mindenkibe bele van írva a természettörvény, mindenki felismerheti azt a saját belső tapasztalatából. „Sem Ádámról, sem senki másról nem lehet sosem kimutatni, hogy a természettörvény nélkül élt volna." Ugyanis amikor Isten megalkotta, akkor belé ültette a természettörvényt az egész emberiség java érdekében. És emellett nem úgy tünik, hogy bárhol is a természettörvényt parancsolatnak nevezné. De ezt Aranyszájú Szent János parancsolatnak, „igazságosnak és szentnek” és „spirituális törvénynek" nevezi. A természettörvény nem a kegyelem eredményeképpen van a tudatban, ugyanis a görögök és barbárok, és más emberek is bírnak e törvény ismeretével. ${ }^{25}$

„Ugyanis Isten volt az, aki a fő cselekvő, ő adta nekünk a természettörvényt és adta mellé az írottat. [...] Dicsérem a törvényt, mondja, a lelkiismeretemben, és azt

21 St. Ambrose, Epistle LI. In St. Ambrose i. m. (5. lj.) 1029.

22 Róm 14,5; St. Jerome: Letter XLVIII to Pammachius. In St. Jerome i. m. (10. lj.) 215.

23 „Amikor Isten megalkotta az embert, akkor a kezdetektől kezdve belé ültette a természettörvényt. És mi volt a természettörvény? Parancsokat adott a bennünk lévő lelkiismeretnek, és minden jó tudása belőle ered." St. Chrysostom: Homily XII Addressed to the People of Antioch. In St. Chrysostom: On the Priesthood. Ascetic Treatises. Select Homilies and Letters. Homilies on the Statutes. Szerk. Philip Schaff. New York, Christian Literature, 1886. 9.

24 St. Augustine i. m. (16. 1j.) 1.

25 St. Chrysostom: Homily XII on Romans. In St. Chrysostom: Homilies on the Acts of the Apostles and the Epistle to the Romans. Szerk. Philip Schaff. Edinburgh, T \& T Clark, 1889. VI.19. 
látom, hogy mellettem szól addig, amíg a jó cselekvésére vágyom, és e vágyamat megerősíti. Amíg örömömet lelem benne, dicséri a döntésemet. [...] Elfogadom helyesnek, mellettem van, ha helyesen akarok cselekedni. És azért a jóra törekvés és rossz kerülése az alapvető részünk a kezdetektől. De a törvény egyszerre erősebb vádló a rossz cselekedet esetén, és a jó nagyobb dicsérője. Megfigyelted, hogy tanúként erőt ad, és más előnyökkel jár, de nem több? Ugyanis noha dicsér és örömünket leljük benne, és a jóra vágyunk, a gonosz még velünk van, és a működését nem lehet felszámolni." ${ }^{26}$

A természettörvény minden emberben meglévő tudása megnevezése lett a synteresis. A skolasztika lelkiismeret-irodalma nagyrészt a conscientia és a synderesis (eredetileg synteresis, de a synderesis forma terjedt el) kapcsolata körül forgott.

Aquinói Szent Tamásig Szent Jeromos Ezékiel látomásáról írt glosszája uralta a lelkiismerettel kapcsolatos gondolkodást. Szent Jeromos sokat emlegetett szerző a lelkiismerettel kapcsolatos irodalomban az új fogalom, a synteresis bevezetése miatt. ${ }^{27}$ A synteresis-conscientia megkülönböztetéssel tudták a keresztény szerzők összekapcsolni a sztoikus és páli lelkiismeret-felfogást: a lelkiismeret egyszerre isteni (vox Dei) és emberi a lelkiismeret csalhatatlan isteni, ugyanakkor esendő emberi volta miatt. Csalhatatlansága a múltra vonatkozó rossz lelkiismeret esetében evidens, míg az esendősége főleg az előremutató - a tervezett cselekvéssel kapcsolatos - ítéletei kapcsán merült fel. De hogyan lehet egyszerre isteni és csalhatatlan, ugyanakkor emberi és esendő? A synteresis és a conscientia megkülönböztetése segített megoldani a bűn és a rossz vagy téves lelkiismeret problémáját: ha van áteredő bűn, akkor hogyan lehetséges, hogy mindenki bír lelkiismerettel (ismeri a törvényt), és felelősségre vonható a rossz tetteiért?

Az Ezékielhez írt kommentár szerint a látomásban szereplő négy szörny a lélek részeinek metaforája: négy teremtmény jön elő a földből, mindegyiknek négy arca van: ember, oroszlán, sas és ökör. ${ }^{28} \mathrm{Ez}$ szerinte a Platón által leírt három lélekrész és a synteresis. Szent Jeromos szerint az emberi arc az emberi racionalitás, az oroszlán az érzelmi rész, az ökör a vágyakozó rész, és a sas a synteresis képe, ami Káinból sem hiányzott: a kiirthatatlan synteresis miatt képes az ember felismerni büneit, és vonható felelősségre.

Szent Jeromos kommentárja az újszövetségi syneidesis helyett a synteresist használta, igaz, eltérő értelemben. A synteresis a szövegben vagy azonos a lelkiismerettel a későbbiekben, vagy annak egy különös része, a szikrája. A synteresis a sztoikus logosz és isteni ész képzetét ôrizte meg a lelkiismeret fogalmában. A kifejezés eredetétől fogva a lelkiismeretre vonatkozott, azzal állt kapcsolatban a görög téreo (felügyel, őriz)

26 St. Chrysostom: Homily XIII on Romans. In St. Chrysostom i. m. (25. lj.) VII. 14.

27 Jerome: Commentary on Ezekiel 1.7. In Timothy C. Potts: Conscience in Medieval Philosophy. Cambridge, Cambridge University Press, 1980. 79-80.; Douglas Kries: Origen, Plato and Conscience ("Synderesis"). Traditio, 57. (2002), 67-83. 
ige alapján. ${ }^{29} \mathrm{~A}$ lelkiismeret a latin sztoikusoknál és Szent Ágostonnál is bírt az őr és nevelő jelentéssel..$^{30} \mathrm{~A}$ synteresis idővel észrevétlenül - zöngésség szerinti részleges hasonulás következtében - synderesis lett, és ebben a formájában terjedt el.

A synderesist kezdettől kitörölhetetlen alapelvnek, habitusnak, hajlamnak tekintették. Csalhatatlan természetes erkölcsi tudásnak, amit közvetlenül, evidensen ismer fel mindenki. Nem döntésen alapul, nem is beleegyezésen. Sérthetetlen és változatlan, azaz az eredendő bűn nem érinti. Miatta hajlik a jóra az ember, és lázad a gonosz ellen. Ez az eredeti erkölcsi integritás maradványa, amit a bünbeeséskor nem vesztett el teljesen az emberiség.

A synderesist a lelkiismeret Istentől eredő szikrájának (scintilla conscientiae) nevezték. A scintilla rationis gondolatát (Isten ismerete az emberben) Szent Ágoston használta az Isten városában, ${ }^{31}$ majd ez a scintilla lett a synderesis értelmezése, és ez a metafora terjedt el általánosan a 12-13. századra. A Jeremiás próféta könyve 31. fejezet 33. versét és A rómabeliekhez írt levél 2. fejezet 15. versét, a „szívbe írt törvényt" a synderesis bibliai megfogalmazásaiként értelmezték a középkorban. Ez a törvény igen egyszerủ: tedd a jót, és kerüld a rosszat, tiszteld az Istent! A jóra sarkall, és a rossz miatt büntet, ezzel vezeti a synderesis az embert a döntésben. A synderesis az újszövetségi emberképhez ${ }^{32}$ és a sztoikus természettörvény-fogalomtárba tartozó conscientia és instinctus naturae - ez jelent meg később Francis Hutcheson erkölcsiérzék-fogalmában - fogalmakhoz kapcsolódott. ${ }^{33}$ A synderesisszel egyező értelemben használták a későbbiekben a recta ratiót, a superior pars rationist, a vertex animaet, a scintilla intelligentiaet és a modicum lument.

Bár Petrus Lombardus idézte a Sententiaeben először Szent Jeromos szövegét, a synderesis fogalma nélkül, a scintilla conscientiaere hivatkozva. ${ }^{34}$ Philippus Cancellarius Summa de bonója volt az első középkori értekezés a lelkiismeretről. ${ }^{35}$ Szerinte a synderesis a conscientia forrása, képesség és lehetőség. A synderesis és conscientia közti viszony ezután lett széles körben vitatott. A synderesis az erkölcsi ítélet általános szintjével foglalkozik, a conscientia pedig a partikuláris szintre, az egyes ese-

29 Robert A. Greene: Synderesis, the Spark of Conscience, in the English Renaissance. Journal of the History of Ideas, 52. (1991), 2. 195-219.

30 Augustinus i. m. (8. lj.) 230.

31 Szent Ágoston i. m. (12. lj.), II. kötet, XXII. könyv 24. fejezet.

32 Róm 8,26; 1 Kor 2,11 és 1 Tessz 5,23.

33 Robert A. Greene: Instinct of Nature: Natural Law, Synderesis, and the Moral Sense. Journal of the History of Ideas, 58. (1997), 2. 173-198.

34 Potts i. m. (26. lj.); Timothy C. Potts: Conscience. In Norman Kretzmann - Anthony Kenny Jan Pinborg (szerk.): The Cambridge History of Later Medieval Philosophy. Cambridge, Cambridge University Press, 1980; Heinrich Appel: Die Lehre der Scholastiker von der Synteresis. Rostock, Universitäts-Buchdruckerei, 1981; Michael B. Crowe: The Changing Profile of the Natural Law. Hága, Martinus Nijhoff, 1977; Oscar J. Brown: Natural Rectitude and Divine Law in Aquinas. Toronto, Pontifical Institute for Medieval Studies, 1981; Joseph V. Dolan: Conscience in the Catholic Theological Tradition. In William C. Bier (szerk.): Conscience: Its Freedom and Limitations. New York, Fordham University Press, 1971. 357-368. Philip the Chancellor: Summa de bono. In Potts i. m. (27. lj.) 94-109. 
tekre vonatkozik. Ez lett a skolasztika és a későbbi kazuisztika lelkiismeret-fogalmának alapszerkezete.

A synderesis szabályokból áll, nem lehet téves, a conscientia e szabályok alkalmazása, ezért tévedhet. Rossz cselekvés csak ott lehetséges, ahol van választás. A conscientia ítélete a premisszákból deduktívan levezetett konklúzió. A szabad választás a gyakorlati szillogizmus propositio minor tételének elfogadásában van, azaz a helyzet értelmezésében. Minden helyzet sokféleképpen leírható, értelmezhető, és mivel az értelmezés lehet téves, ezért ez a téves lelkiismeret és a rossz cselekvés forrása. Így a kérdés az, hogy ki értelmezze a helyzeteket: az Egyház, a világi hatalom, a közösség vagy az egyén? Ha csak az egyénre bízzák, akkor - hacsak nem szent - biztosan fog tévesen dönteni.

A szabály és alkalmazása közti logikai szakadékot a tanítás, képzés igyekszik felszámolni: arra tanítanak a gyakorlatban, hogy miként kell az egyes helyzeteket értelmezni, például mi az, hogy lopni. A synderesis lehetőség, azonban a megszerzett gyakorlati jártasság kell az aktualizálásához. E jártasság egyfajta képesség, amiben az emberek csak mértékben térnek el egymástól, de nem radikálisan. Szemben a patrisztika lelkiismeretével, amely közvetlen felfogás eredménye, ${ }^{36}$ a skolasztika lelkiismeret-fogalma a gyakorlati tudás jelentősége miatt tanítható.

A 13-14. századi lelkiismerettel kapcsolatos írások Lombardust kommentálták. Lombardus kérdése is az volt, hogy miként lehetséges a téves lelkiismeret, ha mindenkiben benne van a synderesis. Majd Szent Tamás foglalta össze és rendszerezte a lelkiismeret irodalmát. ${ }^{37}$ Eszerint a synderesis természettől adott, az emberrel születik, és nem azonos az intellektuális képességekkel (amiket a bűn megrontott). A De veritatében még kérdés volt számára, hogy a synderesis tévedhet-e, de a Summa Theologiaeben már nem az. Szent Tamás is elválasztotta a synderesist a conscientiától - az előbbi szükségszerủ kijelentéseket tartalmaz, természetes és nem intuitív, a természettörvényt tartalmazza, tévedhetetlen és kitörölhetetlen az emberből.

A synderesis állításait okoskodás nélkül ismeri az ember, észszerű beállítottság, ami szemben áll a bủnös hajlammal. A synderesis képesség evidens állítások megfogalmazására és az olyan állítások közvetlenül történő felfogására, mint a $2 \times 2=4$. A synderesis az alapelvek megragadása (idea innata, mint az erkölcsi alapelvek, Isten létének tudása stb.), a belső bizonyosság, evidenciák forrása. A synderesis ösztönös és nem diszkurzív tudás, mint a Marcus Tullius Cicero által használt instinctu divino vagy Titus Livius divino spiritu instinctusa. A conscientia pedig olyan tudás, amelyet az egyes, egyedi esetekre alkalmaznak: mit kell tenni az ilyen és ilyen helyzetben. A conscientia diszkurzív, érvelő értelem és gyakorlati tudás. Ontológiai alapja a synderesis, amely a természettől való, ezért mindenkinek természettől fogva van lelkiismerete. A conscientia a synderesis alkalmazása szillogizmus révén, s ez lett a lelkiismeret intellektualista értelmezésének a magja, ami a kazuisztikát uralja máig.

36 Athanasius: Apologia contra arianos. In Athanasius i. m. (4. lj.) 283.

37 Appel i. m. (33. lj.); Hayden Ramsqay: Conscience: Aquinas - with a Hint of Aristotle. Sophia, 40. (2001), 2. 15-29. 
Szent Tamás a korábbi szerzőknél szorosabban kapcsolta a lelkiismeretet a törvény uralmához: a törvény azzal köt, hogy a törvény követésére szólít fel a lelkiismeret, és megsértéséért büntet. Ez arra is utal, hogy a világi hatalom kényszerítő hatalma (racionális) erkölcsi alapokon nyugodhat, szemben Szent Ágostonnal. ${ }^{38}$ A törvényhozó és alkalmazó a jó lelkiismerete alapján ítélhet, amely a törvény alapján működik. A törvény az értelem müve. ${ }^{39}$

A természettörvények fizikaiak vagy morálisak, amelyek a racionális, szabad lényekre vonatkoznak. Ez utóbbi az ember, aki ezért nem vakon engedelmeskedik, hanem az értelmével felismeri, mit kell tennie. A lex naturalis első szabálya (a synderesis tartalma): a jót kell cselekedni, a rosszat kerülni kell. A jót kell cselekedni, és jó az, ami megfelel az emberi természetnek. Csak a bölcs tud jól cselekedni, mert ő tudja a morális erkölcsi törvényt az egyes esetekhez, változó viszonyokhoz alkalmazni. ${ }^{40}$ Ez egyben a jó lelkiismeret megőrzésének is a módja. A természettörvény (synderesis) nem irtható ki az emberből sem meggyőzéssel, sem romlott szokással, ezért az alkalmazást jelentő gyakorlati szillogizmus fö tételében nem lehet tévedés. ${ }^{41}$ A synderesis a cselekvési elvek, a természettörvény intuitív megragadása (participatio legis aeterna in rationali creatura): kerüld a gonoszt, kövesd a jót, tiszteld az emberi életet, ${ }^{42}$ a jóra való hajlam. ${ }^{43}$ A synderesis csalhatatlan természetes habitus minden emberben. ${ }^{44} \mathrm{Nem}$ lehet teljesen kiirtani, még a kárhozottakból sem. ${ }^{45}$ A cselekvés tévedhet, de a synderesis nem. Egy embertől függetlenül létező erkölcsi rendről tudósít.

$\mathrm{Az}$ ember inherensen racionális, és ismeri a természettörvényt. ${ }^{46} \mathrm{Az}$ alacsonyabb értelem a magasabból ered, és az utóbbi uralja az előbbit. ${ }^{47}$ A szükségszerű igazságokat megragadó „tudó” lélekrész (scientificium animae) elkülönül a véleményalkotótól és okoskodótól, amellyel a kontingens dolgokat ismeri meg. A conscientia a tudás alkalmazása a cselekvésre. ${ }^{48} \mathrm{Ha}$ az értelem benne tévesen ítél, akkor az nem Istentől ered, csak úgy tűnik. Az értelem fényének e hiánya (privatio luminis) a bün eredménye, ugyanis a bün foszt meg az értelem fényétől, az isteni törvénytől. A bün nem pozitív valóság a lélekben, hanem megfosztás, miként az árnyék a fény hiánya, mert egy közbelépő tárgy meggátolja a terjedését. ${ }^{49} \mathrm{Az}$ eredendő bűn nem rombolta le teljesen az em-

38 Henrich A. Rommen: The Natural Law. Indianapolis, Liberty Fund, 1998. 4.

39 St. Thomas Aquinas: Summa Theologiae, (továbbiakban: ST) I-I. q. 90.

40 ST I-II. q. 94.; q. 100.

41 ST I-II. q. 94. a. 5-6. és q. 97. a. 2.

42 ST I-II. q. 94. a. 1-2.; Arisztotelész: Nikomakhoszi etika. Ford. Szabó Miklós. Budapest, Európa, 1997. 1141a.

43 ST I-II. q. 94. a. 2. és I-II. q. 71-77.; Thomas Aquinas: De veritate. In Thomas Aquinas: Quaestiones disputatae. Ford. James V. McGlynn. Chicago, Henry Regnery, 1953. (továbbiakban: De veritate) q. 16. a. 1.

44 ST I. q. 79. a. 12-13.; De veritate q. 17. a. 1.

45 De veritate q. 16. a. 3.

46 Robert S. Smith: Conscience and Catholicism. Lanham, University Press of America, 1998.

47 ST I. q. 79. a. 9.

48 ST I. q. 79. a. 13.

49 ST I-I. q. 86. a. 1. 
beri természetet, ${ }^{50}$ így az értelmet sem. A bủn nem akadályozza meg, hogy az ember bizonyos mértékig értelmes legyen, hiszen ha nem így lenne, akkor többé nem az értelme szerint cselekedne, és akkor nem lenne morális a cselekedete. Még a kárhozatra ítéltben is megmarad az erényre való hajlam nyoma, különben nem érezné a lelkiismeret férgét. De nem mủködik benne az erényre való hajlam, az értelem.

Szent Tamás főképpen tehát az előretekintő (antecedens) conscientiával foglalkozott, a cselekvéselmélettel, és nem a büntető lelkiismerettel. A cselekvés a lelkiismeret következtetése, a lelkiismeret tehát egy ítéletalkotási folyamat. A lelkiismeret cselekedet (actus), ${ }^{51}$ és nem potentia, de habitus is kell legyen, nem csak actus, mivel a lelkiismeret a cselekvés után és előtt (motívum) is jelen van. ${ }^{52}$ Szent Tamás terjesztette el a lelkiismeret új jelentését: az a synderesisben lévő tudás alkalmazása az egyes cselekedetre ${ }^{53}$ A conscientia szillogizmusként müködik, amelynek fö tétele a synderesis, a melléktétele a gyakorlati tudás. ${ }^{54} \mathrm{Az}$ előbbi mindig a jó felé vezeti a cselekvőt.

Az emberi cselekvés a kontingens helyzetek és a valószínűségek kezelése. A kontingenciák miatt lehetséges és szükséges a morális döntés: minden lehetne másképp is. Bár könnyebb jó törvényt hozni, mint jó döntést, a törvény nem képes minden helyzetet specifikálni, az ember nem képes minden helyzetet, kontingenciát előre elgondolni, ezért nem lehet mindent belerakni a törvényekbe. Minden törvényt értelmezni kell a konkrét helyzetben. A törvény ezért eltér a demonstratív igazságtól, ami állandó, és nem kíván alkalmazást. A conscientia a morális, tehát az önkéntes és felelös cselekvésre vonatkozik, ami nem szükségszerü. A conscientia ítéli meg, hogy meg kell-e valamit tenni, azonban ez nem elvek deduktív alkalmazásából ered, hanem összetett a gyakorlati tudás miatt.

A kérdés tehát az volt, hogy tévedhet-e a lelkiismeret, és ha igen, miért, és a téves lelkiismeret kötelez-e. A synderesis sosem téved, a conscientia igen, aminek két forrása lehet: a gyakorlati szillogizmus téves melléktétele (a téves gyakorlati tudás, azaz a helyzet téves megértése) vagy a téves következtetés. A conscientia az ítéletalkotás actusa, ezért a gyakorlati tudáshoz kapcsolódott. A skolasztikus lelkiismeret központi eleme a synderesis mellett a gyakorlati tudás, a phronészisz latin fordítása a prudentia lett, az indokolt ítéletalkotás, előrelátás és körültekintés (circumspectio). ${ }^{55}$

A prudentia fogalmához kapcsolódott a körülmények hangsúlyozása: a változó körülmények közt kap jelentőséget a törvényt alkalmazó lelkiismeret és prudentia. A prudentia a körülmények releváns elemeinek felfogását (gyakorlati tudást) tartalmazta, és a megfelelő döntés meghozatalának képességét (a consiliumot és a iudiciumot). ${ }^{56}$ A könyv latin fordítása vezette be a circumstantia kifejezést. Arisztotelész mellett a kö-

50 ST I-II. q. 85. a. 2. és q. 84. a. 4.

51 ST I. q. 79. a. 13.

52 ST I. q. 79. a. 13.

53 De veritate q. 17. a. 2.; ST II-II. q. 129. a. 13.

54. ST II-II. q. 83. a 1.

55 ST II-II. q. 49 a. 9. Cicero nem használta a circumstantia (környülállás) kifejezést, annak görög változatát (perisztaszisz) Hermagorasz használta. 
rülmények ismeretének hangsúlyozása a cselekvés megítélésében a retorikából és a penitenciairodalomból eredt. A gyakorlati tudás beemelésének másik forrása a retorikai hagyomány volt, ahol Cicero és Marcus F. Quintilianus hangsúlyozta a körülményeket a meggyőzésben, és mindkettőjüknél szerepet kapott a conscientia a helyénvaló (a körülményekhez illeszkedő) cselekvés tárgyalásánál. ${ }^{57}$ A retorika szerint az ítéletalkotás sosem független a körülményektől, az ítélet megbecsüli a valószínűségeket, kontingenciákat, mert a cselekvés mindig esetleges - „másképp is lehet”, legalább „kétféleképpen fogható fel", ezért döntést igényel. ${ }^{58}$

A lelkiismeret ilyen értelmezése és a prudentia beemelése összekapcsolódott a cselekvés sajátos értelmezésével. Eszerint a cselekvés mindig kontingens ${ }^{59}$ mindig szerepe van benne a szabad akaratnak (liberum arbitrium), azaz a cselekvés nem szükségszerü, hanem gyakorlati következtetés terméke, amely következtetés a tapasztalaton alapuló okoskodás, és sok lehetséges változat közül dönt a cselekvő. Az egyes cselekedet esetében az értelem ítélete sok lehetőség felé nyitott, nincs egyhez rögzítve. Ezért fontos a szabad akarat, ${ }^{60}$ amit nem kényszerít szükség. ${ }^{61}$ Morális cselekedet csak az, amelyet a gyakorlati értelem ellenőriz, csak az ilyen lehet vagy jó, vagy rossz.

A prudentia mindkét (arisztotelészi és retorikai) eredete az ítéletalkotást hangsúlyozta, mivel a prudens ítélet nem logikus vagy teoretikus. ${ }^{62}$ Mind a gyakorlati tudás a Nikomakhoszi etikában, mind a retorika olyan helyzetekre vonatkozik, amelyek esetlegesek, cselekvési alternatívákat tartalmaznak, sokféle nézőpontból ítélhetők meg, amelyek egyaránt tarthatók, de egyik sem bizonyítható, és ezért ítéletalkotást igényelnek. ${ }^{63}$ „Gyakorlati [jó] pedig az, ami lehet másképp is." ${ }^{64}$ Ezért bármennyire is intellektualista a tomista lelkiismeret, nem racionalista, mivel az elvek helyes alkalmazása ${ }^{65}$ sosem lesz olyan pontos, mint a matematika, ${ }^{66}$ és ítéletalkotást tartalmaz. Szemben a logikai következtetéssel, a lelkiismeret (a gyakorlati szillogizmus melléktételét adó prudentia) ítéletalkotása sem nem univerzális érvényességü, sem nem kényszerítő. Szent Tamás szerint a változatosság és a bizonytalanság kísérik a cselekvést.

„[E]gyes esetekben még nagyobb a bizonytalanság. [...] Azoknak, akik erkölcsi cselekvést hajtanak végre, mindig ügyelniük kell, hogy az alkalomhoz illően cselekedjenek, mint a gyógyításban vagy a hajózásban. [...] Ennek tanulmányozása nem

57 Edward K. Rand: Cicero in the Courtroom of St. Thomas Aquinas. Milwaukee, Marquette University Press, 1968.

58 Arisztotelész: Rétorika. Ford. Adamik Tamás. Budapest, Gondolat, 1982. 1357a. Smith i. m. (46. lj.); Josef Pieper: Prudence. New York, Pantheon, 1959.

59 ST I. q. 83. a. 1.

60 ST I-II. q. 18. a. 6.

61 ST I-II. q. 10. a. 2.

62 Arisztotelész i. m. (42. lj.) 1141b-1142a.

63 Uo., 1140 a-b; Arisztotelész i. m. (58. lj.) 1357.

64 Arisztotelész: A lélek. In Arisztotelész: Lélekfilozófiai írások. Ford. Steiger Kornél. Budapest, Európa, 1988. 433a, 144.

65 ST I-II. q. 94. a. 5.

66 Vö. Arisztotelész i. m. (42. lj.) II. könyv. 
mesterség vagy hagyomány [követése], mivel az egyéni cselekedetek okai végtelenül sokfélék. Ezért az egyes esetek megítélése mindenki prudenciájára van bízva. Aki prudens módon cselekszik, annak gondosan figyelnie kell a jelenbeli cselekedetére az adott körülmények között. Így kell tenni a gyógyító orvosnak és a hajót kormányzó kapitánynak." ${ }^{67}$

Az embernek ítélnie kell, a conscientia ítéletalkotás, ennek része a prudentia, a helyénvaló észlelés és ítéletalkotás. ${ }^{68}$ Mind Arisztotelész, mind Szent Tamás esetében fontos a gyakorlati ítélet bizonytalanságának elfogadása. A morális okoskodás ezért hasonlít a disputához: számtalan szempont merül fel kezdetben, nincs elvi korlátja, hogy ezek közül mit kell figyelembe venni. A konkrét helyzet sosem szisztematikus, sosem ismerhető ki teljesen, ezért mindig igényli a mérlegelést, értékelést, ami nem a geometriai racionalitáson alapul. A konkrét helyzetben ezért nem lehetséges a teljes bizonyosság, a cselekvés eldöntése sosem demonstratív. A prudentia legfeljebb csak morális bizonyosságot (probabilis certitudo) ${ }^{69}$ tiszteletre méltó véleményt (probabilitast - endoxoszt) érhet el, ami tévedéseket is tartalmazhat. ${ }^{70} \mathrm{Az}$ emberi intellektus korlátozottsága miatt az ember erkölcsi élete a kontingenssel való megbirkózás a probabilitas alapján. De a prudentia terén senki sem teljesen elégséges önmagában. ${ }^{71} \mathrm{~A}$ conscientiát a kegyelem mellett segíti az együttélésbő $l^{2}$ az interakció során keletkező tudás (connaturalitas) is. ${ }^{73} \mathrm{~A}$ tartalmi cselekvési elvek a tapasztalatból erednek, így a lelkiismeret változik a tapasztalattal. ${ }^{74}$ Itt, ebben az összefüggésben jelenik meg a homonoia: a barátság a közös ítéletek meghozatalára vonatkozik. ${ }^{75}$ A prudentia nem természettől adott, a prudentia szempontjából senki sem elégséges önmagában. ${ }^{76}$ A prudentia szétterített tudás. Az ítéletalkotás, az ember természetes képessége megszabadítja az embert a szubjektivitástól, önmagába zártságtól, és a társaihoz kapcsolja.

Bár az esetleges világ teljesen nem ismerhető ki, és az ítéletek lehetnek tévesek, de lehetséges a valószínűleg jó ítélet, a morális bizonyosság. Ez nyilvánvalóan eltér Szent Ágoston erkölcsileg abszurd világképétől, ahol a rossz szándék is eredményezhet jót. A tomista azért értékelhette fel a cselekvést, mert jobban hitt az erkölcsi világ kiismerhetőségében és az emberi értelemben, illetve ez utóbbi fejleszthetőségében.

67 Thomas Aquinas: Commentary on the Nicomachean Ethics, I-II. Ford. C. I. Litzinger. Chicago, Henry Regnery, 1964. II. lectio 2, (Nikomakhoszi Etika 1103 b).

68 De veritate q. 17. a. 5.

69 ST II-II. q. 70. a. 2.

70 ST II-II. q. 70. a. 2.

71 ST II-II. q. 49. a. 3.

72 ST I-II. q. 62. a. 1. A kegyelem az értelem felett áll. (Vö. Korintusiaknak írt második levél és Galátabeliekhez írt levél).

73 ST II-II. q. 45. a. 2.; II-II. q. 28. a. 2.

74 ST II-II. q. 47.

75 Arisztotelész i. m. (42. lj.) 1160a, 28-30, 1167a, 22-30, 1167b, 5-11.

76 ST II-II. q. 49. a. 3. 
A prudentia elemei a memória, a tapasztalat, ${ }^{77}$ az intuitív megértés ${ }^{78}$ (ez a synderesis tartalmára vonatkozik) ${ }^{79}$ és a taníthatóság. Bár a prudentia sok tapasztalati és társas elemet tartalmaz, nemcsak ezekhez, hanem a hithez és a kegyelemhez is kapcsolódik. ${ }^{80}$ Poétikus vagy kegyelemből eredő, de a gyakorlati erény csak a tapasztalati, interszubjektív világból nem eredhet (aminek a keresztények számára nyilvánvaló okai az áteredő bűn okozta problémák az intellektusban). Nem elméleti tudás, ${ }^{81}$ hanem az általános elvek és a konkrét helyzet ismerete. ${ }^{82} \mathrm{~A}$ prudentia az ítéletalkotással és a cselekvéssel áll kapcsolatban. ${ }^{83}$ Az elvek alkalmazása mindig tartalmazza az ítélet problémáját, hiszen az ítélet lehet téves. A jó deliberatio a prudentia műve. ${ }^{84}$ A prudens gyakorlat nemcsak az emlékezetből ered, hanem a jó és hatékony döntések meghozatalának gyakorlatából. ${ }^{85}$ Az ember ugyanis képes nem algoritmus szabályozta cselekvésre, azaz ítéletalkotásra. Gyakran nincs egy kizárólagosan jó lépés, választania kell. Ez a döntés a gyakorlat ismeretét igényli, valamint képzeletet, amely új, még meg nem tapasztalt lehetőségekre vonatkozik. A helyzet jelentése sokféle, és a döntést annak tudatában kell meghozni, hogy más lehetséges alternatívák is vannak. Mindig szakadék van a helyzet és az ítélet között, ami logikailag nem küzdhető le. Ezért az ítélés különös képesség, mindig személyes, felelősséggel és elkötelezettséggel jár. Prudentia nélkül nincs helyes választás (prudentiae acumen - a helyes cselekvés megtalálása), ${ }^{86}$ sem annak végrehajtása.

A prudentia három eleme a nem elméleti, hanem az egyes esetekre vonatkozó ítéletalkotás (synesis) és a rendkívüli helyzetek megítélése (gnome) mellett a képesség a tanulásra (eubulia).$^{87} \mathrm{~A}$ tomista lelkiismeret bár isteni eredetű és belső, igényli a vezetést, támogatást, segítséget. Azaz a tomista lelkiismeretet képezni lehet és kell, ezt szolgálta a kazuisztika, és minden ember kötelessége a lelkiismerete ápolása, gondozása, informálása.

Szent Tamás erősen intellektualizált emberképe szorosan kapcsolódott a jó rend intellektualista képéhez. Mivel a bün forrása a téves lelkiismeret, ami a téves logikai következtetésből vagy téves gyakorlati tudásból ered, ezért a feladat a lelkiismeret ápolása, javítása. Az emberek értelmi képességei (is) egyenlőtlenek. A többség intellektuális fogyatékossága miatt a nálánál bölcsebbek által uralt kell legyen, akik kiigazítják a tévedéseiket. Azonban az uralás csak részben szankcionálás, legalább annyira fontos a tanítás, az intellektuális vezetés. A többség belátva intellektusa korlátait, aláveti magát a bölcsek uralmának, elfogadja a gyakorlati tudása tanítását, vagy időnként

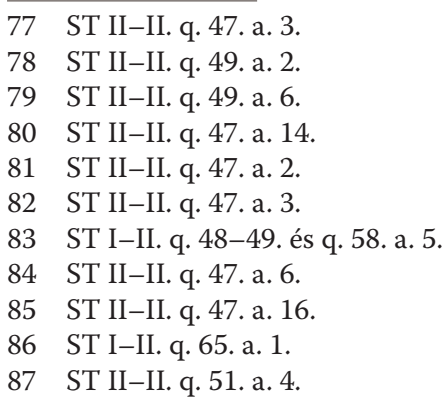


félreteszi a lelkiismeretét, ha tévesen ítélt. Ahogyan az emberi lélek jó rendje egy hierarchián alapul, és a világ is hierarchikus, úgy az emberi kapcsolatok is szükségszerüen hierarchikusak kell legyenek a jó cselekvés érdekében.

Az alárendeltség csak akkor áll összhangban a természettörvénnyel, akkor jogos, ha az elöljáró nem a saját javára használja az alattvalót, hanem annak javára van. A törvények akkor érvényesek, ha megfelelnek a természettörvénynek. ${ }^{88}$ Természetesen az „engedetlenség a feljebbvaló parancsával szemben halálos bűn, ellentétes az Isten iránti szeretettel a Róm 13,2 szerint. [...] [A]z engedetlenség hiúságból ered". ${ }^{89}$ Mivel a bűnbeeséskor az emberi értelem megsérült, ezért kell mindig kényszer is az engedelmesség eléréséhez. A félelem nem baj, hanem jótékony, hiszen visszatartja a bünösöket. ${ }^{90}$ Nem az erényesekkel szemben kell kényszer, hiszen anélkül is engedelmeskednek a törvénynek. A törvény feladata tehát részben a kényszerítés, részben a tanítás a közjó érdekében.

„Az ember alkotta törvények igazságosak, vagy igazságtalanok. Ha igazak, akkor kötelező erejük van a lelkiismeret felett az örök törvény miatt, ahonnan erednek. A Péld 8,15 szerint: Általam kormányoznak a királyok, és tesznek igazságot a tisztségviselők. [...] [A] törvény lehet igazságtalan, mivel szemben áll az isteni jóval: ez a bálványimádásra késztető vagy bármi isteni törvénnyel ellentétes zsarnoki törvény; az ilyen törvénynek sehol sem kell engedelmeskedni, ahogyan az ApCsel 5,29 mondja »Inkább kell engedelmeskedni Istennek, mint az embereknek«. Ez az érvelés érvényes az emberi hatókörön kívül álló Isten parancsaival ellentétes törvényre. Ilyen ügyekben az emberi törvénynek nem kell engedelmeskedni. Ez az érvelés érvényes az alá tartozókat igazságtalanul sértő törvényre. Az Istentől kapott törvény nem terjed ki ezekre, amiért is az ilyen ügyekben az ember nem köteles engedelmeskedni a törvénynek, feltéve, ha nem okoz botrányt vagy nagyobb bajt."11

Ezzel szemben „a zsarnoki törvény, mivel nem értelem szerinti, egyértelműen nem törvény, hanem a törvény perverziója".92 De ezt ki állapítsa meg, és ellen lehet-e neki szegülni? Az igazságtalan törvény nem köti a lelkiismeretet. ${ }^{93}$ De jobb mégis elviselni a zsarnokot, mint lázadni ellene, mert nagyobb bajt hozhat: polgárháborút vagy nagyobb szolgaságot. ${ }^{94}$ Azonban ha magánember nem is, de a köz leválthatja vagy korlátozhatja a zsarnokká lett királyt.

Mivel nem mindenki részesül a kegyelemben, így prudens sem mindenki lett, így a döntéshozatalban sem vehet részt mindenki. Azok nem, akik nem képesek a közjót

88 ST I-II. q. 91. a. 3.

89 ST II-II. q. 105. a. 1.

90 ST II-II. q. 19.

91 ST I-II. q. 96. a. 4.

92 ST I-II. q. 92. a. 1.

93 ST I-II. q. 95. a. 4.

94 Ptolemy of Lucca - Thomas Aquinas: On the Government of Rulers. De regimine principum. Ford. James M. Blythe. University Park, University of Pennsylvania Press, 1997. 1.6. 
belátni. A természettörvényből eredő hierarchiát a közjót szolgáló törvények mellett a feljebbvalók erényessége különbözteti meg a zsarnokságtól. Tulajdonképpen az ő erényességük a fontos, nekik kell jó embereknek lenniük: „Következésképpen az állami közjó nem tud virágozni, ha a polgárok nem erényesek, de legalábbis azok, akik feladata a kormányzás. De az elég a közösség java számára, hogy a többi polgár annyira legyen engedelmes, hogy engedelmeskedik az uralkodójának." ${ }^{\prime 5} \mathrm{~A}$ bünösben a bün lerombolja a természetes hajlamot az erényre, de a jóban „a jó természetes tudása mellett ott van a hit és bölcsesség megkapott tudása, és a jóra való természetes hajlam mellett a kegyelem és erény kapott motívuma. [...] [A] jó teljesen alá van vetve az örök törvénynek, és mindig annak megfelelően cselekszik". ${ }^{\prime 6}$ Azonban egy ember sem képes a saját erőfeszítéseivel megszabadulni a bűntől, és erényessé válni, sem emberi intézmény nem képes erre, csak a kegyelem segít. ${ }^{97}$ A kegyelem javítja fel az ember képességeit, így az értelmét is.

„Így kétféle kegyelem van: az egyik révén az ember maga egyesül Istennel, ezt nevezik szentségi kegyelemnek (gratia sacramentalis), és a másik, amelyik révén az ember másokat vezet Istenhez, amit ingyen kapott kegyelemnek neveznek (gratia gratis data). [...] [D]e ezt nem azért kapja az ember, hogy megigazuljon, hanem hogy segítsen másokat a megigazulásban, ezt nem nevezik szentségi kegyelemnek." ${ }^{98}$

E kegyelemben a papság részesül, akiknek ezért engedelmeskedni kell. A papságnak tehát tanító és fegyelmező, büntető hatalma van.

A forum internum és externum léte tartalmazza a kettő ütközésének lehetőségét. Természetesen a kettő nem ütközhet, ha mindkettőt az isteni törvény működteti. Azonban a gyakorlatban nemcsak a világi és az egyházi hatóságok ütközhettek, de a lelkiismeret ítélete is ütközhetett ezekkel. Mi ilyenkor a teendő, tudva azt, hogy a lelkiismeret tévedhet? A téves lelkiismeret felvetette problémára - köti-e az embert minden esetben a lelkiismerete? - adott válasz magában hordozta a lelkiismeret és a hierarchia ütközésének lehetőségét. A téves lelkiismeret lehetősége és az a kérdés, hogy köteles-e az ember követni az esendő lelkiismeretét, felvetette a skolasztikában a lelkiismeret autoritásának problémáját, amiből kialakult a lelkiismeret szabadságának kérdése. Ugyanis Isten ellen cselekedni és a lelkiismeret ellen cselekedni egyaránt bűn. Mi a teendő, ha a téves (de szubjektíven helyesnek gondolt) lelkiismeretének engedelmeskedve valaki Isten ellen cselekszik?

A lelkiismeret autoritását A rómaiakhoz írt levélre alapozták: ami nem hitből van, az bűn. ${ }^{99}$ Szent Pál szerint a lelkiismeret parancsa mindig köt. A kommentárok

95 ST I-II. q. 92. a. 1.

96 ST I-II. q. 93. a. 6.

97 ST I-II. q. 109. a. 5.

98 ST I-II. q. 111. a. 1.

99 Róm 14,23. 
jellemzően a szövegben szereplő „hit” kifejezést lelkiismeretként értelmezték, majd később erős meggyőződésként: a későbbi értelmezések szerint bűnös a meggyőződés ellen cselekedni, még ha téves is az esetleg. Azonban a téves lelkiismeret másképp kötelez, mint a helyes, ugyanis ha kiderül, hogy téves, akkor félre kell tenni, s nem kötelez többé. Mivel nem tudhatjuk, mikor téves, ezért kell mindig követni, hiszen az embernek arra kell törekednie, amit jónak észlel.

A patrisztikus gondolkodásban a lelkiismeret lett a legfőbb tekintély erkölcsi kérdésekben, ugyanakkor Szent Ágoston szerint bűn az, ami ellentétes az örök törvénynyel, ${ }^{100}$ és ha az embertől teljesen független erkölcsi törvénnyel ellenkezik a lelkiismeret, akkor ez utóbbi nem kötelez. Szent Ágoston prédikációi ${ }^{101}$ szerint a téves lelkiismeret - a szubjektív békés és nyugodt lelkiállapot a bủnben - tehát nem kötelez cselekvésre, vagy nem igazolja azt, hiszen az ember önmaga feletti ítélete a lázadás maga és megbízhatatlan. Ezért a jó lelkiismeret személyes tapasztalata még nem elégséges hivatkozás. ${ }^{102}$ Szent Tamás úgy oldotta meg a problémát, hogy szerinte mindig bűnös a lelkiismeret ellen cselekedni - ez lett a későbbi lelkiismeret-szabadság, és az engedetlenség kötelessége képezeteknek a forrása a kora újkorban. A lelkiismeret ellen cselekedni Isten elleni cselekedet, tehát bünös.

„Ahogyan mondtam, a lelkiismeret semmi más, mint a tudás alkalmazása a cselekvésre. Na most, a tudás az értelemben van. Ezért ha az akarat eltér a téves értelemtől, akkor a lelkiismeret ellen van. De minden ilyen akarat gonosz, hiszen írva van, hogy »Mindaz, ami nem hitből van - azaz a lelkiismeret ellen - az bün « (Róm 14,23). Ezért az akarat bűnös, ha eltér a téves értelemtől."103

A „lelkiismeret, még ha téves is, kötelez”, hiszen Isten parancsának véli a cselekvő. ${ }^{104}$ Az ember pedig köteles megtenni azt, amit Isten parancsának vél, köteles törekedni arra, hogy megtudja, mi Isten parancsa.

Szent Tamás szerint a conscientiát nem követni a synderesis első parancsának (jót kell cselekedni, és a rosszat kerülni) a megsértése. A contra conscientiam agere peccatum vitában Szent Bonaventurához és Szent Tamáshoz köthető két markáns álláspont alakult ki. Az előzőt a lelkiismeret voluntarista, az utóbbit intellektualista értelmezése főbb képviselőjének tekinti a lelkiismeret-irodalom. Szent Bonaventura szerint akkor nem köt a lelkiismeret, ha jó okunk van kételkedni benne. Szent Tamás bírálta Szent Bonaventurát, mivel ö szerinte a téves conscientia nem kötelez. ${ }^{105}$ Ebben a kérdésben Pierre Abélard volt a legradikálisabb, aki szerint a lelkiismeretnek való engedelmes-

100 Xavier G. Colavechio: Erroneous Conscience and Obligations. Washington, Catholic University Press, 1961.

101 St. Augustine i. m. (16. lj.).

102 St. Augustine: Sermon XLIII, 13. In St. Augustine i. m. (16. lj.) 849.

103 ST I-II. q. 19. a. 5.

104 De veritate q. 17. a. 4.

105 ST I-II. q. 19. a. 5. 
ség abszolút parancs. ${ }^{106}$ Isten „nem annyira tetteinket mérlegeli, mint lelkületünket, és maga a cselekedet [...] egyáltalán nem befolyásolja érdemeinket”, ${ }^{107}$ és „ha nem cselekszünk lelkiismeretünk ellen, nem kell attól félnünk, hogy Isten szemében bünösök vagyunk". ${ }^{108}$ A téves lelkiismeret kötelező voltával kapcsolatos vitája során a tomista gondolkodás a bủn fogalmát belsővé tette, azaz oly módon értelmezte át, hogy ezután a bűn rossz szándékot jelentett, és azt, hogy valaki a saját nézetei ellenére - annak ellenére, amit jónak, helyesnek vél - cselekszik.

Szent Bonaventurát is az érdekelte, miként lehet, hogy az ember rosszat tesz, miközben tudja a jót. A választ ő is a lelkiismeret-fogalomban találta meg. A lelkiismeret a korban elterjedt két részre, conscientiára és synderesisre osztása helyett azt három részre osztotta: a természettörvény ismeretére, a tudatossá válás lehetőségére és a beállítottságra. Lehet, hogy valaki felfogja, mit kell tennie, de nem akarja azt megtenni, a tudás ugyanis nem feltétlenül motivál. Ha a tudás motiválná is a cselekvést, akkor nem lenne a bün akarása sem. De az létezik. Szent Bonaventura szerint a bűnre való hajlam nem lényegi eleme az emberi természetnek, míg a synderesis az. A természettörvény tételei (a synderesis) az értelem természetes fénye révén közvetlenül adottak, nem kell tapasztalat a megismerésükhöz. Az alapelvek ilyen belső megismerése intuitív, ami nem vitatható, közvetlen tapasztalat, szemben a prudentiával. Ez az intuicionista lelkiismeret inkább hit, mint tudás, ezért nincs módszer eldönteni, melyik lelkiismeret a helyes. Ebből következhet, hogy minden cselekvést tolerálni kell, ami megegyezik a cselekvő lelkiismeretével. Az intuíció gondolatával jár az is, hogy értelmetlen a próbálkozás valaki lelkiismeretének meggyőzésére vagy megjavítására, mivel ex hypothesi ez a meggyőződés nem argumentatív. Szent Bonaventura szerint a synderesis az akaratban van, az akarat pedig önmeghatározó, nincs az intellektus alá rendelve. Az akarat szabad képesség, míg az intellektus nem az; az akarat választ, az intellektus elfogad. Mivel az akaratnak van jelentősége a cselekvésben, ezért a meggyőzésnek, tanításnak nincs jelentősége, sokkal inkább az akarat megtörésének, az engedelmességnek.

Mindig kell-e követni a lelkiismeret parancsát? Köteles-e az ember cselekedni egy nem megbízható ítélet (lelkiismeret) szerint? Mekkora a lelkiismeret autoritása? Mi a teendő, ha a conscientia - a szubjektív bizonyosság - az isteni törvény elleni cselekedetet parancsol? Ha a lelkiismeret bün elkövetésére utasít, akkor a cselekvés és a nem cselekvés egyaránt bủnös lesz. Az ember mindenképpen bünt követ el. A megoldása az volt, hogy a helyzettől függ a lelkiismeret parancsának ereje. A lelkiismeret parancsa háromféle lehet: az isteni törvénnyel megegyezö, közömbös vagy azzal ellentétes. Az első esetben mindig kötelez a lelkiismeret, a második esetben is. De a harmadik esetben nem kötelez, félre kell tenni. Nem szabad mindig követni a conscientiát, bár rossz ellene cselekedni. Azok az esetek érdekelték, amikor

106 Peter Godman: Paradoxes of Conscience in the High Middle Ages: Abelard, Heloise and the Archpoet. Cambridge, Cambridge University Press, 2009.

107 Abaelardus: Etika. Budapest, MTA, 1989, 56.

108 Uo. 84. 
valakinek oka van gyanakodnia a lelkiismerete parancsára, hátha téves az. Például ilyen eset, ha a conscientia parancsa ellentétes az Egyház parancsával.

„Ezért azt mondom, a lelkiismeret (conscientia) ellen cselekedni mindig bün, mivel az minden esetben engedetlenség Isten ellen, mégis, a lelkiismeret szerint cselekedni nem mindig helyes, mint amikor a lelkiismeret olyasmire utasít, ami Isten ellen van. Arra az ellenvetésre, hogy a lelkiismeret az intellektusunk törvénye, azt kell válaszolni, hogy igen, az egy törvény, de nem a legfőbb törvény. E törvény felett áll valójában egy másik, nevezetesen az isteni törvény. Ezért amikor azt mondják, hogy egy törvény kötelez mindent megtenni, amit elrendel, azt kell válaszolni, hogy ez igaz, ha az alsóbb törvény rendelkezése nem ellenkezik a felsőbbel. De ez az, amit a lelkiismeret gyakran megtesz. [...] [A] lelkiismeret nem kötelez mindenben."109

Szent Bonaventura lelkiismeret-felfogása objektivista - a téves lelkiismeretnek való engedelmesség korlátozott, a szubjektív bizonyosság önmagában nem kötelezi és nem menti fel a cselekvőt -, a lelkiismeret parancsa az isteni törvénnyel egyező vagy annak szempontjából közömbös ügyekben kötelez. A hierarchia parancsa e közömbös ügyekben nem írja felül a lelkiismeret parancsát. A lelkiismeret autoritása az egyházi hierarchia autoritása alá esik az isteni törvény szempontjából fontos ügyekben. A „lelkiismeret nem tud felülírni más törvényeket, nem ment fel Isten elö́rásai alól vagy az elöljáró elöírásai alól, amikhez szerzetesi (vallási) esküvel kötelezi el magát az ember. [...] [N]em kötelezhet a feljebbvaló parancsa ellen". ${ }^{110}$ Ezért az, hogy mikor kötelez a lelkiismeret, és mikor nem, nem igazi dilemma. (Később majd a protestánsok, például John Locke arra hivatkozva tagadták meg a lelkiismeret-szabadságot a katolikusoktól, hogy azok az engedelmességet a lelkiismeret parancsa fölé helyezik.)

„Senkinek sincs ilyen dilemmája, kivéve rövid időre, nevezetesen addig, amíg (téves) lelkiismerettel bír. De még sincs dilemmája egyszerủen mondva, mivel felül kell vizsgálnia a lelkiismeretét. És ha nem képes maga megítélni, mivel nem ismeri Isten törvényét, akkor többet tudó emberekkel kell értekeznie. Vagy Istenhez fordulnia imádsággal, ha emberi tanácsra vágyik. [...] Az is világos, hogy jobban kell törődnie az elöljárója parancsával, mint a lelkiismeretével, főképpen, ha az elöljáró olyasmit parancsol, amire autoritása van, és amit meg kell parancsolni."111

Szent Bonaventura az objektív morált és a hierarchiát összekapcsolta. Ebből fakadóan a perplexust, amelyet a lelkiismeret és a hierarchia parancsának ütközése esetleg okoz, félre kell tenni, hiszen az elöljáró parancsát előnyben kell részesíteni a lelkiismerettel

109 St. Bonaventure, Sententiarium II. 39. 1. In Timothy C. Potts: Conscience in Medieval philosophy. Cambridge, Cambridge University Press, 1980. 114-115.

110 Uo.

111 Uo. 
szemben ilyen esetben. A lelkiismeret esendősége miatt a lelkiismeret szerinti cselekvés nem mindig helyes.

A törvények hierarchiájából más következtetésre jutott Szent Tamás. Szerinte az emberi törvény nem kötelezi a lelkiismeretet, mivel az az isteni törvényen alapul, ami az emberi törvény felett áll. Ezért nem kötelezheti a lelkiismeretet az emberi törvény. A lelkiismeretért a szenvedést is vállalni kell, ${ }^{112}$ mert „[i]nkább kell engedelmeskedni Istennek, mint az embereknek". ${ }^{13}$ Bár ezzel szemben állt $A$ rómaiakhoz írt levél tanítása arról, hogy engedelmeskedni kell a külső ítélőszéknek, és pontosan a lelkiismeret kedvéért. ${ }^{114}$

Szent Tamás írásaiból kiolvasható, hogy az Egyházzal szemben is a lelkiismeretnek kell engedelmeskedni: „az alárendeltek nem alattvalói a feljebbvalóiknak minden ügyben, csak bizonyos dolgokban és bizonyos módon, azon ügyekben, amikben a feljebbvaló Isten és az alárendeltje között áll, míg más ügyekben az alárendelt közvetlenül Isten alatt áll, aki természeti vagy írott törvénnyel tanítja őt."115 A világi hatalomnak a test dolgaiban engedelmeskedni kell, miképpen a hit ügyeit sem lehet bárki döntéseire rábízni: a „magánembernek semmi köze sincs a hit kérdéseiben való döntéshez".116

„Ahogyan mondtam, az egyik ember a másiknak csak a testét kötelezi, a lelkét nem, az megtartja a szabadságát. Na most, ebben az életben Krisztus megszabadított bennünket a lélek hibáitól, de nem a test hibáitól, ahogyan az apostol mondja magáról (Róm 7,23), hogy a tudata Isten törvényét szolgálta, de a teste a bün törvényét. Ezért azok, akik Isten gyermekei, szabadok a bűn spiritális kötelékétől, de nem a testitől, ami a földi urakhoz köti őket, ahogyan az 1Tim 6,1 mondja: »Azok, akik a rabszolgaság igájában görnyednek, adják meg gazdájuknak a teljes tiszteletet, hogy az Isten nevét és tanításunkat ne érje káromlás.« [...] Az embert isteni törvény kötelezi, hogy engedelmeskedjen embertársának. Az ember köteles engedelmeskedni a világi fejedelemnek, amennyire az igazságosság ezt megköveteli. Ha a fejedelem autoritása nem igazságos, hanem zsarnoki, vagy ha igazságtalan parancsot ad, akkor nem köteles engedelmeskedni neki, kivéve alkalmanként, hogy elkerülje a botrányt vagy veszélyt."117

A domonkosok a ferenceseknél elfogadóbbak voltak az alárendeltek lelkiismeretével kapcsolatosan. ${ }^{118}$ Szent Tamás a Summában elutasította a lelkiismeret objektivista értelmezését, de a szubjektivista értelmezés ekkleziológiai implikációival nem foglalkozott itt. A De veritatéban foglalkozott a lelkiismeret ekkleziológiai problémájával,

1121 Pt 2,19.

113 ApCsel 5,29.

114 Róm 13,1.

115 ST II-II. q. 104. a. 5.

116 ST II-II. q. 1. a. 10.

117 ST II-II. q. 104. a. 6.

118 Eric D'Arcy: Conscience and Its Right to Freedom. New York, Fordham University Press, 1971. 
de itt az isteni törvény szempontjából közömbös tettekre koncentrált, nem általában a cselekvésekről írt. Szerinte a cselekvések viszonya az isteni törvényekhez nem állapítható meg objektíven, ezért a cselekvések ferences tipizálása (az isteni törvénnyel megegyező, ellentétes, közömbös) nem alkalmazható. ${ }^{119} \mathrm{~A}$ jó lelkiismeretet nem lehet félretenni, ezért kötelez, így a téves lelkiismeret is jobban köt, mint az elöljáró szava. Az elterjedt értelmezés szerint az, hogy mindig rossz megsérteni a lelkiismeretet, nem jelenti, hogy mindig helyes követni azt. Van olyan helyzet, amikor helyes újragondolni a helyzetet, és az ember köteles engedelmeskedni és karbantartani, alakítani a lelkiismeretét, hiszen a prudentia tartalmazza a consiliumot és a iudiciumot, ${ }^{120}$ és csak a probabilis certitudo érhető el az erkölcsi döntésekben. ${ }^{121}$ Ha a lelkiismeret alakítható, akkor törekedni kell a javítására. Így összeegyeztethető a keresztény erkölcs kettős célja, az, hogy jót kell cselekedni, és engedelmeskedni kell a lelkiismeretnek.

Bár a ferences William Ockham elutasította a tomista intellektualizáló teológiát és antropológiát, amely szerint az értelem képes az isteni igazság megragadására, és az ember legalapvetőbb lelki erejének nem az intellektust, hanem az akaratot tartotta, amit szolgál az intellektus, a lelkiismeret és az (egyházi) autoritás esetleges konfliktusára adott válasza közelebb állt Szent Tamáséhoz, mint Szent Bonaventuráéhoz. Szemben az arisztoteliánusokkal, nem remélte, hogy a törvény egybe eshet a szabadsággal, hanem a kettőt egymás ellentétének látta. Az akarat hangsúlyozása azt jelentette, hogy az akarat autonóm képesség, nem a prudentia szabályozza a cselekvést - Ockham a prudentia helyére az Isten iránti engedelmességet tette -, hanem a külső törvények, kényszer és a nekik való engedelmesség, és engedelmesség a lelkiismeretnek. ${ }^{122}$ Úgy gondolta, hogy az ember nem akarhatja azt, amit nem gondol, és azt akarja, amit jónak gondol a cselekvésben. ${ }^{123}$ Ebből következően, ha téved is, azt kell követnie, amit jónak vél, különben szubjektíven rosszat cselekszik, azaz rossz lesz a lelkiismerete, ami a kárhozat jele és földi valósága. Aki a lelkiismerete parancsának nem engedelmeskedik, az bünt követ el. De mi van, ha a lelkiismeret parancsa és az egyházi elöljáró tanítása, parancsa ellentétesek?

Ockham Szent Tamás dictumát (lelkiismeret ellen cselekedni bűn) radikalizálta. Szent Tamás téves lelkiismerettel kapcsolatos fejtegetésére támaszkodva igényelte, hogy a hívő ellenállhat az eretnek pápának. Szemben a korábbi ferences tanítással (a ferences regulában a lelkiismeret nem korlátozza a szerzetes engedelmességét, és ha a lelkiismeret parancsa ütközik az isteni törvénnyel, akkor félre kell tenni azt, a téves lelkiismeret pedig nem kötelez), szerinte a lelkiismeret tisztaságát megőrzen-

119 De veritate q. 17. a. 5.

120 ST II-II. q. 48.

121 ST II-II. q. 71. a. 2

122 Michael G. Baylor: Action and Person: Conscience in Late Scholasticism and the Young Luther. Leiden, Brill, 1977; Douglas C. Langston: Conscience and Other Virtues: From Bonaventure to MacIntyre. University Park, Pennsylvania State University Press, 2001.

123 Sharon M. Kaye: William of Ockham's Theory of Conscience. Doktori értekezés, University of Toronto, 1997; Eleonore Stump: The Mechanism of Cognition. In Paul V. Spade (szerk.): Cambridge Companion to Ockham. Cambridge, Cambridge University Press, 2006. 
dő - ugyanis a téves lelkiismeret is kötelezi a tulajdonosát - szembe lehet fordulni az egyházi paranccsal, az alázatosság hangsúlyozásával együtt. Ockham szerint a hívő erős meggyőződése, kognitív bizonyossága elégséges igazolás a feljebbvalójával való szembefordulásra, akár a pápa eretnekké nyilvánítására. Ezzel lényegében a felebaráti jó tanács gyakorlatát felszámolta: az Egyház nem javíthatja ki a téves lelkiismeretet. Nem igényelheti az engedelmességet és a téves lelkiismeret félretételét. Hiszen ha valaki úgy gondolja, hogy helyesen gondolkodik, akkor ellenszegülhet a felebaráti jó tanácsnak. ${ }^{124}$ A lelkiismeret kategorikus voltának ekkleziológiai következményeit, az engedelmesség erényével fennálló feszültségét világosan látták a kortársak, noha a probléma tömegesen csak évszázadok múltával jelent meg.

\section{Irodalomjegyzék}

Abaelardus: Etika. Budapest, MTA, 1989.

[Ágoston, Szent] St. Augustine: Sermon on the Mount. Harmony of the gospels. Homilies on the gospels. Szerk. Schaff, Philip. Grand Rapids, Eerdmans, 1886.

[Ágoston, Szent] St Augustine: The Confessions and Letters of St. Augustin. Buffalo, The Christian Literature, 1886.

[Ágoston, Szent] Augustinus, Aurelius: Vallomások. Budapest, Gondolat, 1982.

[Ágoston, Szent] Szent Ágoston: Isten városáról. Budapest, Kairosz, 2005.

[Ambrus, Szent] St. Ambrose: The Treatise concerning Widows. In St. Ambrose: Selected Works and Letters. Szerk. Schaff, Philip - Wace, Henry. Grand Rapids, Eerdmans, 1989.

[Ambrus, Szent] Szent Ambrus: A kötelességről. A bünbánatról. Budapest, Jel, 2004.

Appel, Heinrich: Die Lehre der Scholastiker von der Synteresis. Rostock, Universitäts-Buchdruckerei, 1981.

Arisztotelész: Rétorika. Ford. Adamik Tamás. Budapest, Gondolat, 1982.

Arisztotelész: A lélek. In Arisztotelész: Lélekfilozófiai írások. Ford. Steiger Kornél. Budapest, Európa, 1988.

Arisztotelész: Nikomakhoszi etika. Ford. Szabó Miklós. Budapest, Európa, 1997.

Athanasius: Letter I. In Athanasius: Select Works and Letters. Szerk. Schaff, Philip - Wace, Henry. Grand Rapids, Eerdmans, 1987.

Baylor, Michael G.: Action and Person: Conscience in Late Scholasticism and the Young Luther. Leiden, Brill, 1977.

Brown, Oscar J.: Natural Rectitude and Divine Law in Aquinas. Toronto, Pontifical Institute for Medieval Studies, 1981.

Burr, David: The Spiritual Franciscans. From Protest to Persecution in the Century after Saint Francis. University Park, Pennsylvania State University Press, 2001.

Chancellor, Philip the: Summa de bono. In Potts, Timothy C.: Conscience in Medieval Philosophy. Cambridge, Cambridge University Press, 1980. 94-109. DOI: https://doi.org/10.1017/ CBO9780511609022.012

124 Takashi Shogimen: Ockham and Political Discourse in the Late Middle Ages. Cambridge, Cambridge University Press, 2007. 22.; David Burr: The Spiritual Franciscans. From Protest to Persecution in the Century after Saint Francis. University Park, Pennsylvania State University Press, 2001. 
Chrysostom, St.: On the Priesthood. Ascetic Treatises. Select Homilies and Letters. Homilies on the Statutes. Szerk. Schaff, Philip. New York, Christian Literature, 1886.

Chrysostom, St.: Homilies on the Acts of the Apostles and the Epistle to the Romans. Szerk. Schaff, Philip. Edinburgh, T \& T Clark, 1889.

Colavechio, Xavier G.: Erroneous Conscience and Obligations. Washington, Catholic University Press, 1961.

Crowe, Michael B.: The Changing Profile of the Natural Law. Hága, Martinus Nijhoff, 1977. DOI: https://doi.org/10.1007/978-94-015-0913-8

D’Arcy, Eric: Conscience and Its Right to Freedom. New York, Fordham University Press, 1971.

Dolan, Joseph V.: Conscience in the Catholic Theological Tradition. In Bier, William C. (szerk.): Conscience: Its Freedom and Limitations. New York, Fordham University Press, 1971. 357-368.

Godman, Peter: Paradoxes of Conscience in the High Middle Ages: Abelard, Heloise and the Archpoet. Cambridge, Cambridge University Press, 2009. DOI: https://doi.org/10.1017/ CBO9780511581090

Greene, Robert A.: Synderesis, the Spark of Conscience, in the English Renaissance. Journal of the History of Ideas, 52. (1991), 2. 195-219. DOI: https://doi.org/10.2307/2709525

Greene, Robert A.: Instinct of Nature: Natural Law, Synderesis, and the Moral Sense. Journal of the History of Ideas, 58. (1997), 2. 173-198. DOI: https://doi.org/10.1353/jhi.1997.0014

Isidore: Sententiae. In Schinkel, Anders: Conscience and Conscientious Objections. Amszterdam, Vrije Universiteit, 2007.

Jerome: Commentary on Ezekiel. In Potts, Timothy C.: Conscience in Medieval Philosophy. Cambridge, Cambridge University Press, 1980. 79-80. DOI: https://doi.org/10.1017/ CBO9780511609022.009

Kaye, Sharon M.: William of Ockham's Theory of Conscience. Doktori értekezés, University of Toronto, 1997.

Kries, Douglas: Origen, Plato and Conscience ("synderesis"). Traditio, 57. (2002), 67-83. DOI: https://doi.org/10.1017/S0362152900002701

Lactantius: Isteni tanitások. Ford. Dér Katalin. Budapest, Kairosz, 2012.

Langston, Douglas C.: Conscience and Other Virtues: From Bonaventure to MacIntyre. University Park, Pennsylvania State University Press, 2001.

Pieper, Josef: Prudence. New York, Pantheon, 1959.

Potts, Timothy C.: Conscience. In Kretzmann, Norman - Kenny, Anthony - Pinborg, Jan (szerk.): The Cambridge History of Later Medieval Philosophy. Cambridge, Cambridge University Press, 1980. DOI: https://doi.org/10.1017/CHOL9780521226059

Potts, Timothy C.: Conscience in Medieval Philosophy. Cambridge, Cambridge University Press, 1980. DOI: https://doi.org/10.1017/CBO9780511609022

[Ptolomeo da Lucca - Tamás, Aquinói Szent] Ptolemy of Lucca - Thomas Aquinas: On the Government of Rulers. De regimine principum. Ford. Blythe, James M. University Park, University of Pennsylvania Press, 1997.

Ramsqay, Hayden: Conscience: Aquinas - with a Hint of Aristotle. Sophia, 40. (2001), 2. 15-29. DOI: https://doi.org/10.1007/BF02782384

Rand, Edward K.: Cicero in the Courtroom of St. Thomas Aquinas. Milwaukee, Marquette University Press, 1968.

Rommen, Henrich A.: The Natural Law. Indianapolis, Liberty Fund, 1998.

Schaff, Philip (szerk.): St. Augustine on the Holy Trinity. Doctrinal Treatises. Moral Treatises, III. Buffalo, The Christian Literature, 1887. 
Schaff, Philip (szerk.): The principal works of St. Jerome. New York, Christian Literature, 1892.

Shogimen, Takashi: Ockham and Political Discourse in the Late Middle Ages. Cambridge, Cambridge University Press, 2007. DOI: https://doi.org/10.1017/CBO9780511497223

Smith, Robert S.: Conscience and Catholicism. Lanham, University Press of America, 1998.

Stump, Eleonore: The Mechanism of Cognition. In Paul V. Spade (szerk.): Cambridge Companion to Ockham. Cambridge, Cambridge University Press, 2006.

Thomas Aquinas: De veritate. In Aquinas, Thomas: Quaestiones disputatae. Ford. McGlynn, James V. Chicago, Henry Regnery, 1953.

Thomas Aquinas: Commentary on the Nicomachean Ethics, I-II. Ford. Litzinger, C. I. Chicago, Henry Regnery, 1964.

Thomas Aquinas: Summa Theologiae. Elérhető: https://aquinasinstitute.org/operaomnia/summatheologiae/ (A letöltés dátuma: 2020. 10. 05.) 